\title{
An Analysis of the Adult Education Curricula Implemented in Turkish Universities
}

\author{
Kıymet Selvi, Betül Baldan, Yaprak Alagöz ${ }^{*}$ \\ Faculty of Education, Anadolu University, Turkey
}

Copyright (C) 2016 by authors, all rights reserved. Authors agree that this article remains permanently open access under the terms of the Creative Commons Attribution License 4.0 international License.

\begin{abstract}
The aim of the study to examine the characteristics of the programs conducted by the Continuing Education Centers (CECs), to reveal whether these programs serve for equality, and to identify the institutional barriers related to the CEC programs against adult education. CECs aim to fulfill the educational needs of adults and/or sectors in different fields through the trainings they conduct. In this study, descriptive research method is adopted. The data for this study were collected by examining the 1727 adult education programs through macro analysis, and 83 adult education curricula stated on the webpages of CECs functioning in 57 universities in 2015 were subject to micro analysis. The trainings conducted by CECs were examined according to some criteria such as theme, duration, training fee, mode of instruction, and the features of target audience. Moreover, the curricula of the trainings conducted by CECs were analyzed in terms of objectives, content, teaching-learning processes, and measurement and evaluation. The most important findings of the study involved the inefficiency of the CECs in contributing to the social equality, the lack of standards in curricula and insufficient collaboration with enterprise and other institutions.
\end{abstract}

Keywords Lifelong Learning, Continuing Education Centers, Adult Education, Curriculum, Professional Development

\section{Introduction}

Adult education has been subject to research for many years and the attempts to make it more prevalent have been going on throughout the world. Turkey's attempts to enhance adult learning has led to the foundation of Continuing Education Centers (CECs) within the universities to be such institutions that serve educational opportunities for adults in order to cater the needs of both adults and sectors. Aiming to identify the features of the trainings and the curricula conducted by CECs, this study has three main pillars on which the analyses were built on.

The first pillar of this study is to examine adult education from equality perspective. Adult education has widely been regarded as having a responsibility in contributing to social equality by serving educational opportunities for the women, the elderly, the poor, the handicapped, the minorities who were deprived of educational opportunities [1,24]. Along with the equality perspective, globalization and the notion of knowledge society also attribute special attention and meaning to adult education. As the knowledge society is widely based on scientific knowledge [2], the universities has a role in meeting the needs of industrialization and offer educational services to increase level of education for the whole society [3] and lifelong learning has become one of the major focuses of universities in the new learning market [4]. To serve such educational opportunities, 98 Turkish universities has opened Continuing Education Centers (CECs) or Lifelong Education Centers and begun to offer courses for adults. Although the major premises of the adult education policy documents in Turkey are making adult education more prevalent and contribute to the education for all and especially disadvantaged people [5, 25], Public Education Centers (PEC) in Turkey, which is one of the major institutions for enhancing adult learning, has been identified as being not supportive about equality [6]. However, whether the Continuing Education Centers of the universities, which is another major institution for adult learning along with the PECs, contribute to the educational equality for adults by the pricing policies and the target group they aim for is still unknown.

Adults can participate in adult education due to a variety of motives ranging from making more fiscal gains to get more social bonds [1]. Adults can fail or be discouraged for learning for a variety of reasons, as well. Among these, curriculum or program related ones include poor class organization and management, inadequate resources, and course fees $[1,7,8,9]$. According to Carp et al. [7], three barriers undermining adults' participation in education are situational barriers, institutional barriers and dispositional barriers. Moreover, many researchers pointed out that the fees of courses are among the major obstacles against adult 
education [7-9]. Although Continuing Education Centers of Turkish universities have been serving education for adults for more than a decade and are rapidly spreading around the country, the question of which aspects of their curricula or programs constitute institutional barriers against the prevalence of adult education is yet unanswered, which constitutes the second pillar for the study.

On the other hand, in order for adult education programs to succeed, there is an undeniable need that the curricula of these programs are developed based on the andragogy and needs of the adults (10). A circular model for adult education curricula was stated by [1] which starts with the needs analysis and followed by the aims and objectives, content, methods and resources, assessment and evaluation. In order to address the needs of the adults accurately, adult learners should be included in the decision-making and needs analysis process of the programs [11]. As the adults need to know what and why they are learning [12], it is crucial for CECs to inform the learners about the curriculum and especially the objectives beforehand since in the absence of the aims and objectives, both the instructor and the learners may be lost in the learning process in addition to failing to decide whether the required achievements have been made [1]. Moreover, adult learners are more likely to participate and persist when the expectations from the learners are high and clear [13]. Specification of what the course is about, sensitive initial assessment, guidance for individual students and the utilization of a wide range of methods and approaches can alleviate many problems that may arise in a classroom aimed for adults [1]. Also, the location of teaching, the content of the program and the methods to be used are all part of educational process and they should all relate to the learners, their needs and to their learning styles, which is highly dependent on the expertise of instructional staff [4]. Another important key factor in facilitating adult education is the instructors who have the sufficient quality to support effective learning $[14,15]$. Due to the fact that adults prefer to be actively involved in the learning process rather than to be passive recipients [16], the teaching methods and approaches to be utilized should be learner-centered. As the adults are self-directed [12], adult education programs should implement services to facilitate learners evaluating their progress accomplishing their goals [11]. Since the adults seek for immediacy in learning, the curriculum of adult education programs should be problem- and/or performance-based rather than content-based [12]. According to Caffarella [16], adult education programs can last only an hour or months, can be prepared for small or large groups, and can be delivered online or face-to-face. As the adults need individual guidance and attention, delivering the instruction in small groups can be more effective than large groups. Distance education and online courses have the potential to increase adult participation to education as they need flexibility in the learning process. However, the features of the adult education curricula of the CECs in Turkey have never been examined before, and whether these curricula bear the qualifications for a successful adult education curriculum remains unknown, which constitutes the third pillar of the study.

According to Miser et al. [17] 'the adult education system's main limitation relates to curriculum quality'. In this context, it can be proposed that studies focusing on the current status, objectives, content, learning-teaching process, testing and evaluation, learner profile, duration etc. of the curricula implemented in Turkish universities will contribute to the enhancement of the efficiency of the adult education curricula. In order to be able to determine efficiency of the adult education curricula at universities in Turkey offered by the CECs, these curricula should be analyzed and improved accordingly if needed. However, research on the CECs in Turkey is limited to only two studies conducted by K1lıklı [18] and Bulut [19]. In Kilıklı's study [18], it was aimed to examine the organizational structure and contributions of the CECs to lifelong learning services by analyzing 12 CECs. As a result, it was found out that the courses and training conducted by the CECs are designed by the academicians and administrative board. In addition, it was stated that the budget of the CECs is not supported by any institutions and the activities of the CECs are financed by the income of the trainings. Moreover, it was found out that there is no standard certification policy among the CECs.

Bulut [19] aimed to compare and contrast the current status of the CECs in Turkey and EUCEN-member universities. According to this study, some of the CECs in Turkey only exist by name but do not function at all. Also, some of them do not have a website to be examined. The most frequently offered courses are also related to a profession. It was also pointed out that the fees of the courses are paid by the adult learners. The fact that the prices are high and there is no financial support for adult learners affects the popularity and extensiveness of the CECs negatively. Similar to Kılıklı's [18] study, it was also argued that the problems about certification policy and accreditation undermine the development of CECs and adult education.

However, the fact that there is limited research that aims to analyze the quality and quantity of the adult education curricula conducted by CECs is the most important problem about the adult education carried out at Turkish universities. In this context, the aim of the study to examine the characteristics of the programs conducted by the CECS, to reveal whether these programs serve for equality, and to identify the institutional barriers related to the CEC programs against adult education.

\section{Materials and Methods}

This study is a descriptive research which employs qualitative research method in order to determine and analyze the adult education curricula that are planned and implemented by the Continuing Education Centers (CECs) of Turkish universities through document analysis. 
Table 1. Numbers of the Universities and Sampling Process of the Research

\begin{tabular}{|c|c|c|c|c|c|}
\hline \multicolumn{7}{|c|}{ Macro Level Analysis } & \multicolumn{2}{c|}{ Micro Level Analysis } \\
\hline $\begin{array}{c}\text { The number of } \\
\text { universities in } \\
\text { Turkey }\end{array}$ & $\begin{array}{c}\text { The number of } \\
\text { universities that } \\
\text { own CECs }\end{array}$ & $\begin{array}{c}\text { Those in service } \\
\text { more than 5 years }\end{array}$ & $\begin{array}{c}\text { Websites that do } \\
\text { not have any } \\
\text { information }\end{array}$ & $\begin{array}{c}\text { Total number of } \\
\text { universities } \\
\text { within the sample }\end{array}$ & $\begin{array}{c}\text { Total number of curricula analyzed } \\
\text { courses }\end{array}$ \\
\hline 184 & 98 & 67 & 10 & 57 & 48 \\
\hline
\end{tabular}

\subsection{Sample}

The survey was conducted throughout an eight-month-period, from June 2014 to January 2015. According to the 2014 data, Turkey has 184 universities in total and there are 98 universities in Turkey functioning under the roof of Turkish Universities Continuing Education Centers Council (TUCEC). Aiming to offer more qualified educational services, the CECs of universities gathered under the roof of an upper level institution, TUCEC, in 2011 which was founded in order for CECs to become such institutions that deliver more extensive, active, and qualified education and to enhance their collaboration with national and international institutions [20].

The sample included all the universities which have had Continuing Education Centers at least for five years. Thus, 67 Continuing Education Centers were analyzed in order to acquire information related to adult education curricula based on the information given on their web sites. Ten of 67 CECs do not have any information about the courses offered on the webpages, so at the end of sampling process, the research sample occurred as 57 CECs as seen in Table 1.

For the micro analysis, one course aiming for professional development and one course aiming for personal development from each CEC were randomly chosen and their curricula were analyzed according to criteria determined by the researchers in order to gather detailed data about the courses offered in these 57 CECs. Therefore, 114 adult education curricula were intended to be analyzed, but some of universities did not put any information on their webpages about the curricula of the trainings they offered. Thus, 83 curricula were analyzed in total, 48 of which aims at professional development and 35 of which were related to personal development.

\subsection{Data Collection and Analysis}

The data of the research were acquired from the web pages of universities' CECs. Content and thematic analysis was conducted based on the information related to all of adult learning curricula on the webpages. The trainings were examined according to certain criteria such as theme, duration, training fee, mode of instruction, and the features of target groups. Moreover, the curricula were analyzed in terms of teaching-learning processes, testing and evaluation, and other dimensions of the trainings. During the collection of data, all the adult education curricula were classified as personal development and professional development.

The data collection and analysis were carried out in four different stages. The first stage is related to development of tools that were applied during the data collection process of the research. Both of the tools were developed by the three researchers and two experts gave feedback about them. During the tool development process, tools were pilot-tested two times before collection of the data to improve evaluation criteria. Tool 1 aims for general information about CECs' curricula while Tool 2 searches for very detailed information about 48 vocational and 35 personal development curricula. The second stage included initial analysis of CECs in order to choose and decide research sample. Thus, in this stage, the researchers collected information about all the Turkish universities and the CECs under the roof of TUCEC. The third stage covered macro level analysis of CECs' adult learning curricula. Each of CECs webpages were analyzed by the researchers via Tool 1 to gather general information about the curricula offered by CECs. In the fourth stage, two sample curricula were selected for each of CECs and these curricula were analyzed in depth via Tool 2 to find detailed information about them. Afterwards, thematic and content analysis were carried out by the researchers separately. At the end of the analyses, the reliability of the study was calculated according to the formula suggested by Miles and Huberman [21] and found as 93\%.

\section{Results}

The data obtained from the tools were presented in two sub-sections considering the aim of the study. The findings in the first five tables presented below are related to Tool 1 and occurred as a result of macro analysis. The findings in table 6 to table 11 is comprised of the data gathered from Tool 2 and occurred as a result of micro analysis.

\subsection{General Information about CECs}

In this sub-section, all the trainings offered by 57 CECs were examined in terms of six criteria which can be named as 'informing the target group about the courses, registration procedures, collaboration with institutions, information about the courses, types of courses, and user-friendliness of the websites'. The findings about these criteria are presented in Table 2-6. 
Table 2. Informing the target group about the courses

\begin{tabular}{|c|c|c|c|c|c|c|c|c|}
\hline \multirow{2}{*}{$\begin{array}{l}\text { Informing the target group about the } \\
\text { courses }\end{array}$} & \multicolumn{2}{|c|}{ Existent } & \multicolumn{2}{|c|}{ Non-existent } & \multicolumn{2}{|c|}{ Partially existent } & \multicolumn{2}{|c|}{ Total } \\
\hline & & $\%$ & f & $\%$ & $\mathrm{f}$ & $\%$ & $\mathrm{f}$ & $\%$ \\
\hline $\begin{array}{l}\text { Announcements about the upcoming } \\
\text { courses }\end{array}$ & 43 & 64.1 & 16 & 23.9 & 8 & 12 & 67 & 100 \\
\hline Detailed information about the courses & 23 & 34.3 & 18 & 26.9 & 26 & 38.8 & 67 & 100 \\
\hline
\end{tabular}

Table 3. Information about the courses

\begin{tabular}{|c|c|c|c|c|c|c|c|c|}
\hline & \multicolumn{2}{|c|}{ National } & \multicolumn{2}{|c|}{ International } & \multicolumn{2}{|c|}{ No information } & \multicolumn{2}{|c|}{ Total } \\
\hline & $f$ & $\%$ & $f$ & $\%$ & $f$ & $\%$ & $f$ & $\%$ \\
\hline \multirow[t]{3}{*}{ The origin of the courses } & 1719 & 99.5 & 8 & 0.5 & 0 & 0 & 1727 & 100 \\
\hline & \multicolumn{2}{|c|}{ Vocational } & \multicolumn{2}{|c|}{ Personal } & \multicolumn{2}{|c|}{ No information } & \multicolumn{2}{|c|}{ Total } \\
\hline & $\mathrm{f}$ & $\%$ & $\mathrm{f}$ & $\%$ & $f$ & $\%$ & $\mathrm{f}$ & $\%$ \\
\hline \multirow[t]{3}{*}{ The type of courses } & 1303 & 75.4 & 424 & 24.6 & 0 & 0 & 1727 & 100 \\
\hline & \multicolumn{2}{|c|}{ Cognitive } & \multicolumn{2}{|c|}{ Affective } & \multicolumn{2}{|c|}{ Psychomotor } & \multicolumn{2}{|c|}{ Total } \\
\hline & $\mathrm{f}$ & $\%$ & $\mathrm{f}$ & $\%$ & $f$ & $\%$ & $\mathrm{f}$ & $\%$ \\
\hline Learning Domain & 1549 & 89.8 & 25 & 1.4 & 150 & 8.8 & 1727 & 100 \\
\hline
\end{tabular}

Table 4. The types of the courses

\begin{tabular}{|c|c|c|c|c|}
\hline \multirow{2}{*}{ Type } & \multicolumn{2}{|c|}{ Professional development } & \multicolumn{2}{|c|}{ Personal development } \\
\hline & $f$ & $\%$ & $\mathrm{f}$ & $\%$ \\
\hline $\begin{array}{l}\text { Specific to a field (Engineering, health, } \\
\text { economics, trade etc.) }\end{array}$ & 829 & 63.6 & 0 & 0 \\
\hline Technology & 152 & 11.7 & 0 & 0 \\
\hline Foreign language & 107 & 8.2 & 0 & 0 \\
\hline Research-related & 30 & 2.3 & 0 & 0 \\
\hline Other & 185 & 14.2 & 0 & 0 \\
\hline Foreign language & 0 & 0 & 149 & 35.1 \\
\hline Art and music & 0 & 0 & 91 & 21.5 \\
\hline Sports & 0 & 0 & 43 & 10.1 \\
\hline Communication skills & 0 & 0 & 38 & 9 \\
\hline Other & 0 & 0 & 103 & 24.3 \\
\hline Total: & 1303 & 100 & 424 & 100 \\
\hline
\end{tabular}

Table 5. Registration procedures

\begin{tabular}{|c|c|c|c|c|c|c|c|c|}
\hline \multirow{2}{*}{ Registration } & \multicolumn{2}{|c|}{ Internet } & \multicolumn{2}{|c|}{ In person } & \multicolumn{2}{|c|}{ No information } & \multicolumn{2}{|c|}{ Total } \\
\hline & $\mathrm{f}$ & $\%$ & $f$ & $\%$ & $\mathrm{f}$ & $\%$ & & $\%$ \\
\hline Pre-registration & & 64.9 & 4 & 7 & 16 & 28.1 & 57 & 100 \\
\hline Mode of registration & 5 & 8.8 & 8 & 14 & 44 & 77.2 & 57 & 100 \\
\hline
\end{tabular}

Table 6. Collaboration with institutions

\begin{tabular}{|c|c|c|c|c|c|c|c|c|c|c|}
\hline \multirow{2}{*}{ Collaboration } & \multicolumn{2}{|c|}{ Private } & \multicolumn{2}{|c|}{ Public } & \multicolumn{2}{|c|}{ Both } & \multicolumn{2}{|c|}{ No information } & \multicolumn{2}{|c|}{ Total } \\
\hline & f & & $\mathrm{f}$ & $\%$ & $\mathrm{f}$ & $\%$ & $\mathrm{f}$ & $\%$ & & $\%$ \\
\hline National institutions & 7 & 12.3 & 2 & 3.5 & 7 & 12.3 & 41 & 71.9 & 57 & 100 \\
\hline International institutions & 2 & 3.5 & 1 & 1.8 & 0 & 0 & 54 & 94.7 & 57 & 100 \\
\hline
\end{tabular}


When the results are analyzed, it can be seen that $64.1 \%$ of the websites examined provide the learners with the announcements about the upcoming courses. While 23.9\% of them do not have any announcements at all, $12 \%$ of these websites have partial announcements about the courses to be offered soon. While $34.3 \%$ of the websites include detailed information about the courses offered, almost the same number of the universities includes partial information about the courses. However, a considerable number of webpages do not provide any detailed information about the courses; which is equal to 18 of $67 \mathrm{CECs}$

Based on the results obtained, it can be seen that almost half of the CECs did not provide sufficient information about the courses they offer. However, this is a deficient practice in terms of adult education, which can be regarded as an institutional barrier against the adult learning. The main reason of this practice may be the fact that the administrators, their assistants and the instructors who work in the CECs are not experts in their field.

As seen in Table 3, 1727 separate courses are being offered by 57 CECs. While 1719 of them are offered on national basis, only 8 of them are on international basis. $75.4 \%$ of the courses are conducted for professional purposes and $24.6 \%$ of them seek to attain personal development. Considering the dominant learning domain, most of the courses concentrates on cognitive domain with a percentage of 89.9 . While $8.8 \%$ of the courses focus on psychomotor domain, affective domain is high ly neglected considering the number of the courses focusing on this domain.

All of the vocational programs are designed on national basis. Moreover, the fact that nearly all of the vocational courses are related to the cognitive domain shows us that there is a crucial problem in adult education. Especially the negligence about the psychomotor and affective domain and perception that adult education only aims for cognitive domain imply us that the courses conducted by the CECs are prepared and offered without taking the adults' needs into consideration, which can be stated as an institutional barrier against adult education.

As seen in Table 4, 63.6\% of the vocational courses offered by CECs are specific to a vocational field or profession. $11.7 \%$ of the vocational courses are related to technology. $8.2 \%$ of the vocational courses aims to improve foreign language skills in a way that can assist learners' professional careers. While $2.3 \%$ of the vocational courses seek to provide learners with research skills, $14.2 \%$ of the vocational courses are related with other aspects of professional development.

As to the courses aiming at personal development, 35.1\% of them are related with foreign languages. $21.5 \%$ of them focus on different branches of art or music. $10.1 \%$ of the personal courses are related with sports. While $9 \%$ of the personal courses concentrates on communication skills, $24.3 \%$ of them are related to other topics regarding personal development.

Considering the types of courses offered by the CECs, $75 \%$ of the courses aim for professional development while $25 \%$ of the courses aim for the personal development. In the context of adult education, this finding is quite compelling in terms of showing us that the adult education is mostly regarded as vocational training by the CECs. However, theoretically adult education comprises of both the professional and personal development of the individuals. Therefore, the aims and functions of the CECS should be revised in terms of adult education and new courses aiming for personal development should be designed in order to meet the needs of adults.

As seen in Table 5, most of the universities tend to prefer online forms to handle pre-registration processes with a percentage of 64.9 . Along with this preference, $7 \%$ of the CECs require personal contact to get in touch with the applicants. In an ironic way, $28.1 \%$ of the CECs do not provide the learners with any information about how to register for the courses. When it comes to the exact registration procedures, $77.2 \%$ of the CECs do not give any information about the procedures to be followed while $8.8 \%$ of CECs specify the internet as the registration instrument and $13.8 \%$ of them require application in person.

The common utilization of internet in pre-registration process has made the learners benefit from the technological advances. However, the lack of information about the registration process can be regarded as a disadvantage about the participation of adults. This result shows that the CECs fail to inform the participants about the registration, which can lead to adults' withdrawal from the courses and can be a barrier to adult education.

As seen in Table $6,12.3 \%$ of 57 CECs indicate that they make collaboration with national private institutions. While $3.5 \%$ of them make collaboration with national public institutions, $12.3 \%$ of them have collaborative bonds with both public and private institutions. On the other hand, only one of the CECs examined in this study makes collaboration with international public institutions along with two others making collaboration with international private institutions.

When the courses conducted by the CECs are examined, it can be seen that the ratio of the national or international collaboration is quite low. In other words, universities do not make collaborations with other institutions about the preparation and execution of the adult courses. Moreover, poor collaboration with international institutions can lead to a decrease in the quality of the courses along with the implication that universities are quite strict about sharing their knowledge and experience. The inadequate collaboration with national and international institutions can be regarded as another barrier against adult education.

As to the data regarding the "user-friendliness of CECs" websites" shows that $28.4 \%$ of the webpages are user-friendly. While $37.3 \%$ of them are partially effective, $34.3 \%$ of them are stated as non-user-friendly. 
Table 7. Informing the target group about the vocational and personal courses

\begin{tabular}{|c|c|c|c|c|c|c|c|c|c|c|c|}
\hline & \multicolumn{2}{|c|}{ Existent } & \multicolumn{2}{|c|}{ Non-existent } & \multicolumn{3}{|c|}{ Partially existent } & \multicolumn{4}{|c|}{ Total } \\
\hline & Vocational & Personal & Vocational & Personal & Voc & tional & Personal & Voc & tional & & onal \\
\hline & f $\quad \%$ & $\mathrm{f} \quad \%$ & $\mathrm{f} \quad \%$ & $\mathrm{f} \quad \%$ & $\mathrm{f}$ & $\%$ & $\mathrm{f} \quad \%$ & $\mathrm{f}$ & $\%$ & & $\%$ \\
\hline Announcements & $\begin{array}{ll}40 \quad 83.3 \\
\end{array}$ & $29 \quad 82.9$ & $\begin{array}{ll}8 & 16.7 \\
\end{array}$ & $\begin{array}{ll}6 & 17.1 \\
\end{array}$ & 0 & 0 & $\begin{array}{ll}0 & 0 \\
\end{array}$ & 48 & 100 & 35 & 100 \\
\hline $\begin{array}{c}\text { Detailed } \\
\text { information }\end{array}$ & $10 \quad 20.8$ & $4 \quad 11.4$ & 0 & & 38 & 79.2 & 3188.6 & 48 & 100 & 35 & 100 \\
\hline
\end{tabular}

\section{2. The Detailed Analysis of Professional and Personal Courses' Curricula}

Twelve basic criteria were determined to examine the curricula of the courses which focus on professional development and personal development. These criteria consist of 'informing the target group about the courses, the topic of the courses, the length of the courses, registration procedures, pricing, criteria for the learners to attend the course, the size of the group, teaching and learning processes, terms for fulfilling the requirements of the course, collaboration with institutions, employment, and user-friendliness of the website. The findings related to the detailed analysis of the curricula are presented in Table $7-11$

As seen in Table 7, there are announcements about $83.3 \%$ of 48 vocational and $82.9 \%$ of 35 personal courses on the webpages of the CECs. While there is detailed information about $20.8 \%$ of the vocational courses, there is only partial information about $79.2 \%$ of them. Similarly, $11.4 \%$ of the personal courses have detailed descriptions on the webpages while there is only partial information about $88.6 \%$ of them.

According to Table 7, CECs put announcements about most of the upcoming courses on their websites, which can help the adults learn about the courses to be offered. However, detailed information about these courses are only partially existent, which can undermine the adult participation as they are not informed well.

When the courses are classified, $66.6 \%$ of 49 vocational courses analyzed are specific to a vocational field or profession such as Mathematics, Science, Engineering, Business Administration, health and so on. $14.6 \%$ of them are related to technology as seen in Table $8.4 .2 \%$ of the vocational courses aims to improve foreign language skills in a way that can assist learners' professional careers. While $6.3 \%$ of the vocational courses seek to provide learners with research skills, $8.3 \%$ of the vocational courses are related with other aspects of professional development. As to the courses aiming for personal development, $25.7 \%$ of them are related with foreign languages. $22.9 \%$ of them focus on different branches of art or music. $11.4 \%$ of the personal courses are related with sports. While $8.6 \%$ of the personal courses concentrates on communication skills, $31.4 \%$ of them are related to other topics regarding personal development.

Examining the genres of the courses offered by the CECs, we can see that these genres mainly cover the topics universities teach in undergraduate and graduate level. Also, it is found out that only 35 universities from our sample offer adult education programs related to personal development. However, adult education covers both the professional and personal development of the individuals. As a result, it can be said that the CECs offering only vocational courses are a barrier against the adult education and they should focus on the adults' personal development as much as they focus on their professional development.

Table 8. The types of vocational and personal courses

\begin{tabular}{|c|c|c|c|c|}
\hline \multirow[t]{2}{*}{ Type } & \multicolumn{2}{|c|}{$\begin{array}{l}\text { Professional } \\
\text { Development }\end{array}$} & \multicolumn{2}{|c|}{$\begin{array}{c}\text { Personal } \\
\text { Development }\end{array}$} \\
\hline & $\mathrm{f}$ & $\%$ & $\mathrm{f}$ & $\%$ \\
\hline $\begin{array}{c}\text { Specific to a field } \\
\text { (Mathematics, } \\
\text { Science, Engineering, } \\
\text { Business } \\
\text { Administration, } \\
\text { Health etc. ) }\end{array}$ & 32 & 66.6 & 0 & 0 \\
\hline Technology & 7 & 14.6 & 0 & 0 \\
\hline Research-related & 3 & 6.3 & 0 & 0 \\
\hline Foreign language & 2 & 4.2 & 0 & 0 \\
\hline Other & 4 & 8.3 & 0 & 0 \\
\hline Other & 0 & 0 & 11 & 31.4 \\
\hline Foreign language & 0 & 0 & 9 & 25.7 \\
\hline Art and music & 0 & 0 & 8 & 22.9 \\
\hline Sports & 0 & 0 & 4 & 11.4 \\
\hline Communication skills & 0 & 0 & 3 & 8.6 \\
\hline Total: & 48 & 100 & 35 & 100 \\
\hline
\end{tabular}

In the Table 9 , it can be seen that while $95.8 \%$ of the vocational courses focus on cognitive domain, $4.2 \%$ of them are on psychomotor domain. On the other hand, $65.7 \%$ of personal courses belong to cognitive domain. While $25.7 \%$ of the courses concentrate on psychomotor domain, only $8.6 \%$ of them are oriented towards affective domain. Similar to the results of the macro analysis, cognitive domain is the most dominant domain while the psychomotor domain and affective domain is highly disregarded.

As to the length of courses, half of the vocational courses are offered as short-term while 27.1 of the courses are medium-term and $20.8 \%$ of them are long-term programs. There is no information about the length of $2.1 \%$ of the vocational courses. $71.4 \%$ of the personal courses are designed as short-term courses. $20 \%$ of them are labelled as medium-term. However, none of the personal courses analyzed is considered as long-term courses along with 
$8.6 \%$ of the courses with no information about their length. Although adult education programs can last for a couple of hours or even months [16], in order to create permanent changes in behavior, adult education programs should be mostly medium or long-term, which will give the instructors and the learners enough time for meaningful and permanent learning.

It can be stated that internet is the main and the most frequent instrument for the pre-registration to the courses. $60.4 \%$ of the vocational and $65.7 \%$ of the personal courses require to deal with the pre-registration through internet. While $10.4 \%$ of the vocational and $5.7 \%$ of the personal courses require personal contact for pre-registration, $29.2 \%$ of the vocational and $28.6 \%$ of the personal courses do not specify how to deal with the pre-registration procedures. As to the exact registration, there is no information about how to register to $70.8 \%$ of the vocational and $72.2 \%$ of the personal courses. $6.3 \%$ of the vocational and $5.6 \%$ of the personal courses utilize internet as the registration instrument. While $22.9 \%$ of the vocational courses require personal contact for registration, $19.4 \%$ of the personal courses use the same registration pattern. The fact that there is not sufficient information about the registration on the websites is congruent with the results of the macro analysis and a barrier against the enhancement of participation in adult education.

As to the pricing of the courses, $\% 72.9 \%$ of the vocational and $82.8 \%$ of the personal courses are paid. While $2.1 \%$ of the vocational and $2.9 \%$ of the personal courses are free of charge, there is no information about the pricing policy of $25 \%$ of the vocational and $14.3 \%$ of the personal courses. $77.1 \%$ of the vocational and $94.3 \%$ of the personal courses are paid by the individuals attending the course. However, there is no information about $22.9 \%$ of the vocational and $5.7 \%$ of the personal courses in terms of by whom they are paid. Seen in Table 9, there is no discount policy in $43.8 \%$ of the vocational and $37 \%$ of the personal courses. There is discount for students in $25 \%$ of the vocational and $23.9 \%$ of the personal courses, for the university personnel in $20.8 \%$ of the vocational and $21.7 \%$ of the personal courses, for the employees working in public institutions in $2.1 \%$ of the vocational and $8.7 \%$ of the personal courses and for other applicants in $8.3 \%$ of the vocational and $6.5 \%$ of the personal courses based on different criteria. Lastly, there is discount for applicants based on their age in only $2.2 \%$ of the personal courses.

The fact that most of the courses are paid -generally by the adults- and there is no discount in almost half of the courses show us that these courses are only available for those who can already afford them. However, adult education should be a second chance for those deprived of educational opportunities like the elderly, the women, the less affluent, the minorities etc. who are also deprived of economical opportunities to afford education [1]. Moreover, the fact that discounts are only available for the university staff or students along with those who are working in public institutions strengthens the conclusion that courses conducted by CECs aim to meet the professional or personal education needs of who are currently employed. The current pricing and discount policies of the CECs show us that they fail to contribute to the equality by providing education for those who can afford rather than for all.

Table 9. Detailed information about the vocational and personal courses

\begin{tabular}{|c|c|c|c|c|c|}
\hline & & \multicolumn{2}{|c|}{ Vocational } & \multicolumn{2}{|c|}{ Personal } \\
\hline & & $\mathrm{f}$ & $\%$ & $\mathrm{f}$ & $\%$ \\
\hline \multirow{4}{*}{ Learning domain } & Cognitive & 46 & 95.8 & 23 & 65.7 \\
\hline & Affective & 0 & 0 & 3 & 8.6 \\
\hline & Psychomotor & 2 & 4.2 & 9 & 25.7 \\
\hline & Total: & 48 & 100 & 35 & 100 \\
\hline \multirow{5}{*}{$\begin{array}{l}\text { The length of the } \\
\text { courses }\end{array}$} & $\begin{array}{c}\text { Short-term (1-60 } \\
\text { hours) }\end{array}$ & 24 & 50 & 25 & 71.4 \\
\hline & $\begin{array}{c}\text { Medium-term } \\
(60-180 \mathrm{~h} .)\end{array}$ & 13 & 27.1 & 7 & 20 \\
\hline & $\begin{array}{c}\text { Long-term }(180+ \\
\text { hours) }\end{array}$ & 10 & 20.8 & 0 & 0 \\
\hline & No information & 1 & 2.1 & 3 & 8.6 \\
\hline & Total: & 48 & 100 & 35 & 100 \\
\hline \multirow{4}{*}{ Pre-registration } & Internet & 29 & 60.4 & 23 & 65.7 \\
\hline & In person & 5 & 10.4 & 2 & 5.7 \\
\hline & No information & 14 & 29.2 & 10 & 28.6 \\
\hline & Total: & 48 & 100 & 35 & 100 \\
\hline \multirow{4}{*}{ Registration } & Internet & 3 & 6.3 & 2 & 5.6 \\
\hline & Mail & 0 & 0 & 1 & 2.8 \\
\hline & In person & 11 & 22.9 & 7 & 19.4 \\
\hline & No information & 34 & 70.8 & 26 & 72.2 \\
\hline & Total: & 48 & 100 & 36 & 100 \\
\hline \multirow{4}{*}{ Pricing } & Free & 1 & 2.1 & 1 & 2.9 \\
\hline & Paid & 35 & 72.9 & 29 & 82.8 \\
\hline & No information & 12 & 25 & 51 & 4.3 \\
\hline & Total: & 48 & 100 & 35 & 100 \\
\hline \multirow[t]{7}{*}{ Discount } & No discount & 21 & 43.8 & 17 & 37 \\
\hline & For age & 0 & 0 & 1 & 2.2 \\
\hline & For students & 12 & 25 & 11 & 23.9 \\
\hline & For personnel & 10 & 20.8 & 10 & 21.7 \\
\hline & $\begin{array}{l}\text { For public } \\
\text { employees }\end{array}$ & 1 & 2.1 & 4 & 8.7 \\
\hline & For others & 4 & 8.3 & 3 & 6.5 \\
\hline & Total: & 48 & 100 & 46 & 100 \\
\hline \multirow{4}{*}{$\begin{array}{l}\text { Criteria for the } \\
\text { course to be } \\
\text { offered or taken } \\
\text { by the applicants }\end{array}$} & No criterion & 25 & 48 & 24 & 68.5 \\
\hline & $\begin{array}{l}\text { Criteria for } \\
\text { readiness }\end{array}$ & 71 & 3.5 & 1 & 2.9 \\
\hline & $\begin{array}{l}\text { Criteria for } \\
\text { group size }\end{array}$ & 20 & 38.5 & 10 & 28.6 \\
\hline & Total: & 52 & 100 & 35 & 100 \\
\hline \multirow{4}{*}{$\begin{array}{l}\text { The features of } \\
\text { the target group }\end{array}$} & $\begin{array}{l}\text { Small group } \\
(2-20)\end{array}$ & 11 & 22.4 & 7 & 20 \\
\hline & $\begin{array}{l}\text { Large group } \\
\quad(+20)\end{array}$ & 7 & 14.3 & 4 & 11.4 \\
\hline & No information & 31 & 63.3 & 24 & 68.6 \\
\hline & Total: & 49 & 100 & 35 & 100 \\
\hline
\end{tabular}

Some of the courses have some criteria in order for the 
course to be offered or in order for applicants to attend the course. As seen in Table $9,13.5 \%$ of the vocational and $2.9 \%$ of the personal courses have criteria for readiness to be met by the applicants. While $38.5 \%$ of the vocational and $28.6 \%$ of the personal courses have criteria about group size, $48 \%$ of the vocational and $68.5 \%$ of the personal courses have no criterion for the course to be offered. It is found out that there is generally no criterion for the programs to be offered and the criteria established are about how many people will be in the classes. The fact that the criteria for the courses to be offered are not established properly is a crucial problem for the adult education.

As to the group size, $22.4 \%$ of the vocational and $20 \%$ of the personal courses are conducted with small group ranging from 2 learners to 20 learners. $14.3 \%$ of the vocational and $11.4 \%$ of the personal courses are offered for large groups referring to 21 learners and more. Unfortunately, there is no information about the group size about $63.3 \%$ of the vocational and $68.6 \%$ of the personal courses. The absence of information about the size of the target group shows that these courses are offered for everyone who demands for the course without paying any special attention to the group size.

It can be seen in Table 10 that $26.8 \%$ of the vocational and $20.8 \%$ of the personal courses aim for people aged between 18 and $26.34 .8 \%$ of the vocational and $20.8 \%$ of the personal courses are for people aged between 26 and 60 . While $29.5 \%$ of the vocational and $20.8 \%$ of the personal courses are for people aged over 60 , there is no information about the target age group of $8.9 \%$ of the vocational and $24.6 \%$ of the personal courses. Lastly, $13 \%$ of the personal courses aim for children aged between 0 and 18 . Since 48 vocational and 35 personal courses are examined, it is found out that most of these courses aim for people aged between 18-60+. This result shows that the courses of the CECs aim for elder people along with other age groups, which can contribute to the social equality providing educational opportunities for them.

According to the data, $48 \%$ of the vocational and $47.2 \%$ of the personal courses take place in the facilities of the universities. While $6 \%$ of the vocational and $5.6 \%$ of the personal courses take place outside the university, there is no information about the place of the courses in $46 \%$ of the vocational and $47.2 \%$ of the personal courses. The fact that half of the courses are delivered in the university and the location of other half is unknown, it can be said that using the facilities of the universities can enhance the adult learning as universities generally have a broader range of learning environments such as laboratories or ateliers etc., while the unspecified learning environment can be a barrier against adult education as insufficient information may lead the learners to lose interest.

$46.3 \%$ of the vocational and $38.9 \%$ of the personal courses take place in classrooms. While $7.4 \%$ of the vocational and $2.8 \%$ of the personal courses are conducted in laboratories, only $5.6 \%$ of the vocational courses take place in e-learning environment. Moreover, $1.8 \%$ of the vocational and $11.1 \%$ of the personal courses take place in other facilities such as gymnasium, atelier etc. Lastly, there is no information about $38.9 \%$ of the vocational and $47.2 \%$ of the personal courses in terms of the places in which the lessons take place. The lack of information about the learning environment in almost half of the courses can be deficiency in terms of adult education and a sign that the managers and other staff of the CECs are not expert in preparing adult education programs. On the other hand, the fact that almost half of the courses are conducted in classrooms gives the implication that the methods used in these courses may be traditionally teacher-centered.

As to the mode of instruction, $47 \%$ of the vocational and $50 \%$ of the personal courses are conducted face-to-face. While $6.2 \%$ of the vocational courses adopt blended instruction, $13.6 \%$ of the vocational and 15.2 of the personal courses are applied courses. Theoretical courses constitute $15.1 \%$ of the vocational and $8.7 \%$ of the personal courses. Unfortunately, there is no information about $18.2 \%$ of the vocational and $26.1 \%$ of the personal courses in terms of the mode of instruction. The fact that almost half of the courses are conducted face-to-face and blended learning or distance education is not utilized can be a barrier against making the adult education more available and prevalent.

As for the instructors, $43.8 \%$ of the vocational and $37.1 \%$ of the personal courses are conducted by academicians. While $4.2 \%$ of the vocational and $11.4 \%$ of the personal courses are conducted by instructors who work in the related sector, $14.5 \%$ of the vocational and $8.6 \%$ of the personal courses are conducted by a team of instructors comprised of both academicians and instructors from the sector. Nevertheless, there is no information about $37.5 \%$ of the vocational and $42.9 \%$ of the personal courses in terms of their instructors. Being taught by the academician, almost half of the courses are delivered by the experts in their fields. Moreover, employing people from the sector as instructors can enrich the programs with their experience. However, whether these academicians or instructors from the sector have the required andragogy knowledge is still unknown in addition to having no information about who the instructors are of one fourth of the courses.

Although there is no information about $80 \%$ of the vocational and $77.1 \%$ of the personal courses in terms of the materials used in teaching-learning process, in $6 \%$ of the vocational and $2.9 \%$ of the personal courses, printed resources are utilized based on the data. While technological resources such as computers or projectors are utilized in $8 \%$ of the vocational and $8.6 \%$ of the personal courses, e-resources are only used in $2 \%$ of the vocational courses. Other materials are also adopted by $4 \%$ of the vocational and $11.4 \%$ of the personal courses. Based on this result, it is found out that adult education curricula of the CECs do not generally specify the materials to be used, which can be a hurdle against the adult participation as the adults need to know what is to be learned or covered by which materials. 
Table 10. Detailed information about the curricula of the vocational and personal courses

\begin{tabular}{|c|c|c|c|c|c|}
\hline & & \multicolumn{2}{|c|}{ Vocational } & \multicolumn{2}{|c|}{ Personal } \\
\hline & & $\mathrm{f}$ & $\%$ & $f$ & $\%$ \\
\hline \multirow{6}{*}{$\begin{array}{l}\text { The age span of } \\
\text { the target group }\end{array}$} & The child $(0-18)$ & 0 & 0 & 10 & 13 \\
\hline & The young (18-26) & 30 & 26.8 & 16 & 20.8 \\
\hline & The adult (26-60) & 39 & 34.8 & 16 & 20.8 \\
\hline & The old $(60+)$ & 33 & 29.5 & 16 & 20.8 \\
\hline & No information & 10 & 8.9 & 19 & 24 \\
\hline & Total: & 112 & 100 & 77 & 100 \\
\hline \multirow{4}{*}{$\begin{array}{l}\text { The place of } \\
\text { the course }\end{array}$} & $\begin{array}{l}\text { Within the } \\
\text { university }\end{array}$ & 24 & 48 & 17 & 47.2 \\
\hline & $\begin{array}{l}\text { Outside the } \\
\text { university }\end{array}$ & 3 & 6 & 2 & 5.6 \\
\hline & No information & 23 & 46 & 17 & 47.2 \\
\hline & Total: & 50 & 100 & 36 & 100 \\
\hline \multirow{6}{*}{$\begin{array}{l}\text { The learning } \\
\text { environment }\end{array}$} & Laboratory & 4 & 7.4 & 1 & 2.8 \\
\hline & Classroom & 25 & 46.3 & 14 & 38.9 \\
\hline & E-learning & 3 & 5.6 & 0 & 0 \\
\hline & Other & 1 & 1.8 & 4 & 11.1 \\
\hline & No information & 21 & 38.9 & 17 & 47.2 \\
\hline & Total: & 54 & 100 & 36 & 100 \\
\hline \multirow{6}{*}{$\begin{array}{l}\text { Mode of } \\
\text { instruction }\end{array}$} & Face-to-face & 31 & 47 & 23 & 50 \\
\hline & Blended & 4 & 6.1 & 0 & 0 \\
\hline & Applied & 91 & 3.6 & 71 & 5.2 \\
\hline & Theoretical & 10 & 15.1 & 4 & 8.7 \\
\hline & No information & 12 & 18.2 & 12 & 26.1 \\
\hline & Total: & 66 & 100 & 46 & 100 \\
\hline \multirow{5}{*}{ The instructor } & Academicians & 21 & 43.8 & 13 & 37.1 \\
\hline & $\begin{array}{l}\text { Employees from } \\
\text { the sector }\end{array}$ & 2 & 4.2 & 4 & 11.4 \\
\hline & Both & 7 & 14.5 & 3 & 8.6 \\
\hline & No information & 18 & 37.5 & 15 & 42.9 \\
\hline & Total: & 48 & 100 & 35 & 100 \\
\hline \multirow{6}{*}{ Materials } & Printed resources & 3 & 6 & 1 & 2.9 \\
\hline & E-resources & 1 & 2 & 0 & 0 \\
\hline & $\begin{array}{l}\text { Technological } \\
\text { resources }\end{array}$ & 4 & 8 & 3 & 8.6 \\
\hline & Other & 2 & 4 & 4 & 11.4 \\
\hline & No information & 40 & 80 & 27 & 77.1 \\
\hline & Total: & 50 & 100 & 35 & 100 \\
\hline
\end{tabular}

In $18.9 \%$ of the vocational and $2.8 \%$ of the personal courses, exam scores are the basis to determine the success of the learners. While participation is the criterion for success in $18.9 \%$ of the vocational and $2.8 \%$ of the personal courses, project completion is adopted as the success criterion in only $1.9 \%$ of the vocational courses. In $7.5 \%$ of the vocational and $16.6 \%$ of the personal courses, attendance is the main criterion to determine the success level. Unfortunately, there is no information about $52.8 \%$ of the vocational and $77.8 \%$ of the personal courses in terms of criteria for success.
Table 11. Information about the testing and evaluation processes of the vocational and personal courses

\begin{tabular}{|c|c|c|c|c|c|}
\hline & & \multicolumn{2}{|c|}{ Vocational } & \multicolumn{2}{|c|}{ Personal } \\
\hline & & $\mathrm{f}$ & $\%$ & $\mathrm{f}$ & $\%$ \\
\hline \multirow{9}{*}{$\begin{array}{l}\text { Testing and } \\
\text { evaluation }\end{array}$} & Written exam & 6 & 11.1 & 0 & 0 \\
\hline & Oral exam & 1 & 1.9 & 0 & 0 \\
\hline & Applied exam & 0 & 0 & 1 & 2.7 \\
\hline & $\begin{array}{c}\text { Project } \\
\text { evaluation }\end{array}$ & 1 & 1.9 & 0 & 0 \\
\hline & Exam & 4 & 7.4 & 1 & 2.7 \\
\hline & Participation & 9 & 16.6 & 1 & 2.7 \\
\hline & No evaluation & 4 & 7.4 & 6 & 16.2 \\
\hline & No information & 29 & 53.7 & 28 & 75.7 \\
\hline & Total: & 54 & 100 & 37 & 100 \\
\hline \multirow{6}{*}{$\begin{array}{l}\text { Criteria for } \\
\text { success }\end{array}$} & Exam scores & 10 & 18.9 & 1 & 2.8 \\
\hline & Participation & 10 & 18.9 & 1 & 2.8 \\
\hline & $\begin{array}{c}\text { Project } \\
\text { completion }\end{array}$ & 1 & 1.9 & 0 & 0 \\
\hline & $\begin{array}{l}\text { Attending the } \\
\text { course }\end{array}$ & 4 & 7.5 & 6 & 16.6 \\
\hline & No information & 28 & 52.8 & 28 & 77.8 \\
\hline & Total: & 53 & 100 & 36 & 100 \\
\hline \multirow{6}{*}{ Certification } & Certificate & 25 & 52.1 & 3 & 8.6 \\
\hline & $\begin{array}{c}\text { Participation } \\
\text { document }\end{array}$ & 6 & 12.5 & 5 & 14.3 \\
\hline & Both & 2 & 4.2 & 0 & 0 \\
\hline & No document & 1 & 2.1 & 2 & 5.7 \\
\hline & No information & 14 & 29.1 & 25 & 71.4 \\
\hline & Total: & 48 & 100 & 35 & 100 \\
\hline
\end{tabular}

Learners who successfully finish the courses are given certificates at the end of $52.1 \%$ of the vocational and $8.6 \%$ of the personal courses. In $12.5 \%$ of the vocational and $14.3 \%$ of the personal courses, learners are given a participation document at the end of the course. In $4.2 \%$ of the vocational courses, learners are given both certificate and participation document. While there is no document given in $2.1 \%$ of the vocational and $5.7 \%$ of the personal courses, there is no information about $29.1 \%$ of the vocational and $71.4 \%$ of the personal courses in terms of certification policy.

In conclusion, the fact that there is no information about half of the vocational and most of the personal courses can be regarded as a crucial barrier against the adult education since the adults need to get a concrete reward at the end of learning. This result also shows us that there is no standard certification policy among CECs regarding adult education.

\section{Discussion}

In this study, it is aimed to analyze the adult learning curricula conducted by the universities in Turkey in the scope of equality, curriculum properties and CEC-related barriers against adult education. The courses conducted by CECs which function under the universities in Turkey was analyzed in this research on macro and micro level. 
Based on the results, it is found out that the personal courses conducted by the CECs are offered for almost all age groups while vocational courses aim for all individuals aged above 18. Providing a wide range of age groups with educational opportunities, CECs seem to contribute to social equality in some way for especially elder people. However, we found out that CECs do not offer courses specifically for disadvantaged adults like the minorities or handicapped people. Moreover, it is found out that most of the courses offered by the CECs are paid -generally by the learners-, which shows that CECs only aim for learners who have the financial stability to afford education and probably are already employed. Also, it is found out that only $3 \%$ of both vocational and personal development courses are free and the information about pricing and payment about some courses were missing on the webpages. As it was stated by Kilıklı [18], CECs are financed only by the payments of the trainees. This result about the pricing in our study can be explained with the dependence of the CECs on the income of the courses paid by the trainees. In other words, if it were not for these payments, it would be impossible for the CECs to offer courses as they are not financially supported by the government or any other institutions. However, that the learners have to pay for education and courses are not available for those who are unemployed or deprived of educational background to earn enough to pay for education show that these disadvantaged adults are pushed from adult education and the CECs of the universities only function or serve for those who have the required educational background to afford more education. In terms of contributing the social equality, CECs of the universities are incompetent as the Public Education Centers which are another prominent centers for adult education [6]. These results lead to the conclusion that "education is a form of production whereas learning is a form of consumption - the learning society is a consumer market" [4]. As the CECs do not get any financial support from the government or the universities' budget, the roots of the role that CECs play in promoting social inequality can be found in educational policies of the government and Higher Education Council which are the supreme and ultimate policy maker for universities in Turkey.

As to the institutional barriers against adult education, firstly, it is found out that there is insufficient information and announcements about the courses which can hinder the adult participation in the courses. Also, poor information about the registration processes stated on the websites can be regarded as another barrier against the prevalence of adult education since the lack of related information can lead learners to give up on signing for the course. It is also found out that only 14 universities have collaboration with national institutions and 3 universities with international institutions. This result shows that the universities are strict about sharing knowledge and experience with other institutions and also missing out the opportunity to benefit from other institutions' experience, which can be a barrier against adult education by negatively affecting the quality of the instruction given to adults. The deficiency of the universities in collaborating with others raises the question that there might be some bureaucratic or other kinds of obstacles; however, these probable obstacles are beyond the focus of this study and requires further research.

Another barrier against the prevalence of adult education is the inefficiency of the websites with partially existent detailed information about the courses. As the internet is a very common communication means, preparing more efficient websites and providing more detailed information about the courses can help the adults to be aware of the courses that they might be interested in. Besides, although the CECs of the universities require internet-based application for courses, there is not sufficient information about these courses on their websites, which can be regarded as a contradiction.

According to the results, 1303 of 1727 courses are related to professional development of the adults while only 424 of them aim for their personal development. Moreover, some CECs do not offer any courses related to the personal development at all. These results indicate that the primary focus of the CECs is on offering vocational courses which might stem from the fact that universities are highly competent in vocational education due to their experience in undergraduate and graduate programs and might lack in academic competence and teaching staff expert in personal development of the individuals. However, adult education encompasses the development of all aspects of adults including professional, personal, cognitive, psychomotor, affective and even moral facets [4]; and adult education in Turkey theoretically seeks to meet the educational needs of the adults throughout their lives regardless of whether these needs are related to their professional or personal development $[22,25]$. As a matter of fact, according to the results of the study carried out by Taşc1 et al. [23], the primary aim of adults in participating in education is personal development followed by acquisition of a profession and getting a certificate. In this context, the CECs which do not offer personal development courses or focusing heavily on vocational education can be regarded as another barrier hindering the prevalence of adult education since they neglect to meet the personal development needs of adults.

As the results indicate, $89.8 \%$ of the 1724 courses offered by the CECs aim for cognitive domain, $8.8 \%$ of them aim for psychomotor domain and 1.4 of them aim for affective domain, which shows that affective and psychomotor domain is highly neglected. This negligence implies that these programs may have been designed without taking the needs of the adults into consideration and adult education is perceived mainly by the CECs as the development of cognitive domain, which can undermine adult education as the educational needs of the adults regarding the affective and psychomotor domain are unmet.

Since the half of the vocational courses and $71 \%$ of the personal courses are short-term courses which last less than 60 hours in total, it can be inferred that the quality of these 
courses and permanence of the adults' learning is questionable due to the fact that short-term courses might be unable to provide the learners and instructors with the required time resource to achieve educational objectives, which can be regarded as another barrier against the adult education.

Congruent with the results of the study conducted by Kilıklı [18], CECs are found to have no standard certification policy. Moreover, 3 of 83 courses, analyzed in detail, do not provide any documents or certificates at the end of the courses while 39 of them do not provide any information about the certificates or documents to be given. However, certification of the courses contributes to the validity of the learning and serves for one of the basic motives of adult learners in participating in education [23]. Although the modularization and accreditation of the courses for adults was firstly proposed in 1960s [4] and has been one of the primary aims of TUCEC [20], it is seen that this policy has not yet effectively put in practice in Turkey. Therefore, the absence of certification, unstandardized certificates, and poor information about the certificates or documents to be given can be viewed as obstacles undermining the adult education.

Last institutional barrier related to the CECs is identified as their pricing policies which gives only the adults who can afford the chance to get education. According to the findings about pricing policy, 64 of the 83 courses are paid by the learners and in 38 of them there is no discount for any learner profile. However, that the learning is required or provided or paid by the employer increases the participation of adults in education [26] in addition to open courses that requires no payment for the learners.

As for the properties of curricula implemented by the CECs, due to the insufficient information stated in websites of the CECs, many aspects of the curricula such as objectives or methods and approaches could not be analyzed. As the adult learners need to know why they are learning [12], the specification of the objectives and informing the learners about these objectives is a crucial component of adult education programs. Also, adults tend to attend courses at the right level and relevant to their needs in addition to matching their abilities [1]. Therefore, the inadequacy of the curricula and the lack of information about the programs constitutes a risk against the adult learning.

Despite the deficiencies in the curricula of the CECs, a holistic overview of these curricula could still be obtained based on the results of this study. Firstly, with 69 curricula out of 83 , it can be concluded that most curricula implemented by the CECs are cognitive-domain-oriented and affective and psychomotor domain are highly neglected. As 49 of the 83 curricula is planned as short-term, it can be concluded that middle-term or long-term courses are not frequently offered neither favored by the CECs. The adult education programs of the CECs generally do not specify the size of the group for which the courses are offered. Moreover, more than half of the programs do not specify any criterion for learners to be able to take the course. As 41 programs out of 83 are conducted within the universities using their facilities, it can be stated that university facilities are the biggest physical resources for adult education programs of the CECs. Almost half of the instructors who teach for the courses of the CECs are comprised of academicians. As academicians are experts in their subject field, employing them in adult education can be regarded as a strength. However, the andragogy knowledge of these academicians and their competence in adult teaching still remain unanswered, which calls for further research. According to the results, the primary mode of instruction adopted by the CECs is face-to-face instruction with a number of 54 out of 83 , and blended learning or distance education is not utilized very commonly. However, the flexible learning environment provided by distance education can contribute to the increase in adult participation in education by allowing them to attend a course they are interested in any time they are available [23]. It has been also found out that in almost half of the courses the materials to be used in the learning process are not specified and the specified ones include printed, online and technological resources. According to the results, more than half of the programs do not specify the testing and evaluation process they conduct and 1 in every 8 programs do not require any testing and evaluation process at all. Besides, the adult education curricula of the CECs have mostly undefined criteria for success with 56 programs out of 83 which provides no information about the criteria.

As a result of this study, it can be stated that the information about the continuing education programs and curricula stated on the webpage of the CECs are not detailed enough to inform the adult learners, which undermines the development and increase of efficiency of the programs offered by the CECs along with the prevalence of adult education. As the learners are not adequately informed, their participation to the programs can be negatively affected. All these give us the implication that the current situation of the CECs undermines the success of adult education in general.

\section{Conclusions}

In this study it is aimed to examine the characteristics of the programs conducted by the CECS, to reveal whether these programs serve for equality, and to identify the institutional barriers related to the $\mathrm{CEC}$ programs against adult education.

The results about the pricing and discount policies and target group that CECs aim for indicate that the CECs of the universities do not contribute to the enhancement of social equality. However, because of the inadequate information in the webpages of the CECs, further studies on a larger scale can be conducted to clarify the current role, function and contribution of CECs to social equality in the context of adult education.

According to the results of this study, it is evident that there are many barriers caused by the CECs threatening the 
enhancement of adult education, which can be stated as the insufficient information and announcements about the courses, inadequate collaboration with national or international institutions, negligence about the personal development of the adults and affective and psychomotor domain, the length of the courses, and non-standard certification policies.

The results regarding the properties of the curricula implemented in CECs indicate that these curricula seem to be designed without taking the needs of adults, basic curriculum development procedures, and features of adults, -namely andragogy- into consideration. Based on the results, it can be deduced that most of the curricula analyzed in this study have been developed or designed by the people who are neither experts nor experienced in adult education and curriculum development.

The insufficient information stated in the webpages of the CECs is the primary indicator of the fact that CECs and TUCEC are unable to form an efficient infrastructure. These deficiencies should be reconsidered and eliminated by taking the necessary precautions by making the CECs function under the supervision and management of the universities. Although the CECs of universities gathered under the roof of TUCEC to function more properly and collaborate more, it is seen that there no standards regarding the design, implementation, administration and supervision of the adult education curricula, which shows that TUCEC fails to fulfill its duties towards the CECs and undermines the quality of these programs. Therefore, further studies regarding the standards of adult education programs in CECs should be carried out and action plans should be implemented to make these programs more effective and efficient.

In adult education centers like CECs which requires knowledge and experience in adult teaching, learning and curriculum, employing academicians who are both competent in adult education and curriculum design, development, implementation and evaluation will contribute to the functionality and performance of these centers. Designing adult education curricula without having the necessary theoretical and applied knowledge about adult learners and curriculum development will lead to problems and affect the quality of these programs negatively. Employing people who have expertise in education as the administrators of the CECs will contribute to the implementation of more qualified programs. Also, further research on the programs conducted by CECs which utilizes single or multiple case study design will provide a deeper insight about the CECs and bring about an understanding regarding the causal relationships between the findings of this study.

\section{REFERENCES}

[1] J. Daines, C. Daines, B. Graham.Adult Learning and Adult Teaching (3rd ed.), Publications Unit Department of Adult Education University of Nottingham, Nottingham, 1993.

[2] N. Stehr. The Knowledge Society, Sage, London, 1994.

[3] C. Kerr, J. Dunlop, F. Harbinson, C. Myers. Industrialism and Industrial Man (2 ${ }^{\text {nd }}$ ed. $)$, Penguin, Harmondsworth, 1973.

[4] P. Jarvis. Adult Education and Lifelong Learning ( $3^{\text {rd }}$ ed.), Routledge Falmer, New York, 2004.

[5] Ministry of National Education. Turkey Lifelong Learning Strategy Document and Action Plan: 2014-2018. Online available from

http://hbogm.meb.gov.tr//meb_iys_dosyalar/2015_04/20025 555 hbostratejibelgesi 2014 $201 \overline{8}$.pdf

[6] E. Bağc1. Yetişkin Eğitimi ve Eşitlik, Kalkedon, İstanbul, 2014.

[7] A. Carp, R. E. Peterson, P. J. Roelfs. Adult learning interests and experiences, in K. P. Cross, J. R. Valley, et al.(Eds.), Planning non-traditional program, Jossey-Bass, San Francisco, 11-52, 1974.

[8] A., Charnley, M. Osborn, A. Withnall. Review of Existing Research in Adult and Continuing Education: Vol. 1 Mature Students, NIAE, Leicester, 1980.

[9] N. Sargant, J. Field, H. Francis, T. Schulder, A. Tuckett. The Learning Divide. NIACE, Leicester 1997.

[10] M. S. Knowles. Androgogy: An emerging technology for adult learning, in Education for Adults (M. Tight ed.), Routledge, New York, 2012.

[11] S. Kerka. Learner persistence in adult basic education, California Adult Education Research Digest 2, 1-4, 2005.

[12] M. S. Knowles. The Making of an Adult Educator, Jossey Bass, San Francisco, 1989.

[13] V. Tinto. Taking retention seriously: Rethinking the first year of college, NACADA Journal, 19(2), 5-9, 1999.

[14] S. Kerka. Strategies for retaining adult students: the educationally disadvantaged, ERIC Digest No. 76, 1-6, 1988.

[15] P. Comings. Persistence: Helping Adult Education Students Reach Their Goals, National Center for the Study of Adult Learning and Literacy, 2007.

[16] R. S. Caffarella. Planning Programs for Adult Learners: A Practical Guide for Educators, Trainers and Staff Developers, Jossey-Bass, San Francisco, 2002.

[17] R. Miser, O. Ural, O. Ünlühisarcıkl1. Adult education in Turkey, Adult Learning, Vol.24, No.4, 167-174, 2013.

[18] M. K1lıklı. Türkiye Üniversitelerindeki Sürekli Eğitim Merkezlerinin Yapısı ve İşleyişi (Unpublished master's thesis). Muğla University, Muğla, Turkey, 2008.

[19] B. Bulut. Sürekli Eğitim Merkezlerinin Ülkemiz ve Bazı Ülkelerdeki İşleyişi. (Unpublished master's thesis). Kırıkkale University, Kırıkkale, Turkey, 2009.

[20] TUCEC. About TUCEC Council, 2015, Online available from http://www.tusemkonseyi.org.tr/ 
[21] M. Miles, M. Huberman. An expanded sourcebook qualitative data analysis. (Second ed.). California: Sage Publications, 1994.

[22] R. Miser. Halk Eğitimi ve Toplum Kalkınması, Meb Yayınları, Ankara, 1999.

[23] D. Taşc1, C. H. Aydın, E. G. Kumtepe, A. T. Kumtepe, G. K. Kıcır, G. D. Dinçer. Eskişehir'de Yaşam Boyu Öğrenme Başlığı Altında Yetişkin Eğitiminin Analizi, Selçuk Üniversitesi Sosyal Bilimler Enstitüsü Dergisi, Vol. 35,
197-211, 2015.

[24] E. Bağc1. Evaluation of Adult Education Expenditures in Turkey in the Context of Equality, Ankara University Journal of Faculty of Educational Sciences, Vol.47, No.1, 145-170, 2014.

[25] Ministry of National Education. Lifelong Learning Strategy Document: Turkey, 2009, online available from http://mesbil.meb.gov.tr/genel/hayat $\% 20$ boyu $\% 20 \% \mathrm{C3} \% \mathrm{~B} 6$ $\%$ C4\%9Frenme $\% 20$ dokuman.pdf 